\title{
THE ATTRIBUTE ASSESSMENT PROCESS AT THE UNIVERSITY OF MANITOBA: YEAR TWO
}

\author{
Jillian Seniuk Cicek, Sandra Ingram, and Nariman Sepehri \\ Faculty of Engineering, University of Manitoba, Winnipeg, MB, Canada R3T 5V6 \\ Corresponding author E-mail address: umseniuk@cc.umanitoba.ca
}

\begin{abstract}
This paper describes the process in the second year of a three year study at the University of Manitoba that looks at how the 12 CEAB graduate attributes are manifested and measured in the engineering curriculum. The four attributes chosen for this year's study were Problem Analysis, Use of Engineering Tools, Communication Skills, and Ethics and Equity. Nine instructors from each of the Departments of Biosystems, Civil, Electrical and Computer, and Mechanical Engineering were asked to consider the presence of these attributes in one of their engineering courses taught in Fall 2012. The checklist for this study was revised based on the results of the pilot study conducted in 2011-12, and in an effort to begin to define student attribute competency levels and demonstrate outcomes-based assessment. Similar to last year, this study found that the hard skills in engineering were assessed more frequently than the soft skills, and in particular, there was little assessment evidence of Ethics and Equity. The majority of instructors reported using assignments and reports as evaluation tools, and communicating evaluations to students using numerical marks and written comments. Competency levels were defined in a variety of ways, highlighting the need to establish a common language for assessment. Finally, this paper reports on the challenges observed in the construction and administration of the survey and outlines next steps.
\end{abstract}

Keywords: attribute assessment; accreditation; faculty checklist.

\section{INTRODUCTION}

In 2011 the Faculty of Engineering at the University of Manitoba ( $U$ of $M$ ), initiated a faculty attribute assessment pilot study. This study was envisioned as a 3year longitudinal study, where each year 4 of the 12 Canadian Engineering Accreditation Board (CEAB) graduate attributes would be targeted to examine how they were manifest and measured in each of our five engineering programs: Biosystems, Civil, Electrical, Computer, and Mechanical Engineering. The long term objectives of this research are to: (i) investigate how the CEAB attributes manifest in the $U$ of $M$ engineering curriculum; (ii) reflect on how they are measured; (iii) explore the extent to which the measurable attributes result in course content proficiency. The attributes designated for each year of the study were chosen to reflect what are considered both the traditional or "hard" skills of engineering and the professional or "soft" skills [10]. The research is based largely on instructors' responses to a self-administered checklist.

The pilot study, conducted in 2011-2012, examined eight senior level engineering courses over two terms (4 courses each per Fall/Winter term) targeting four graduate attributes: Investigation, Design, Professionalism and Lifelong Learning [3]. Initial findings pointed to evidence that instructors were teaching and assessing the four targeted attributes to varying degrees, with more evidence of assessment of the hard skills of engineering [3]. In addition to these findings, it was observed that a large percentage of students scored B (3.0 GPA) or above in the targeted indicators measured. However, at the time the study was implemented, instructors were not asked to express what this assessment represented, for example, whether a B or above indicated student competency. The pilot study concluded that more research was needed to define levels of student learning competency for each attribute and their individual indicators.

It was therefore determined that for the second year of this study, a fourth objective would be added to the long term objectives initially defined: to explore what instructors determine as the level that represents student competency for each attribute/indicator. Additionally, rather than examining one course from each program per term, 2 would be targeted. This would be done to increase data and shift the focus of analysis onto each program. This approach more closely reflects the autonomy our engineering programs have within the faculty's combined efforts for program improvement.

\section{METHODS}

The four graduate attributes that were chosen to launch the second year of our study in Fall 2012 were Problem Analysis, Use of Engineering Tools, Communication Skills, and Ethics and Equity. These 4 attributes and their associated indicators, as originally created by the faculty, were developed into a new checklist for the Faculty Attribute Assessment plan 2012-2013, as shown in Fig. 1. This year's checklist included two additional categories: Level that Indicates Competency and Assessment Results. 
U of M Faculty Attribute Assessment Checklist

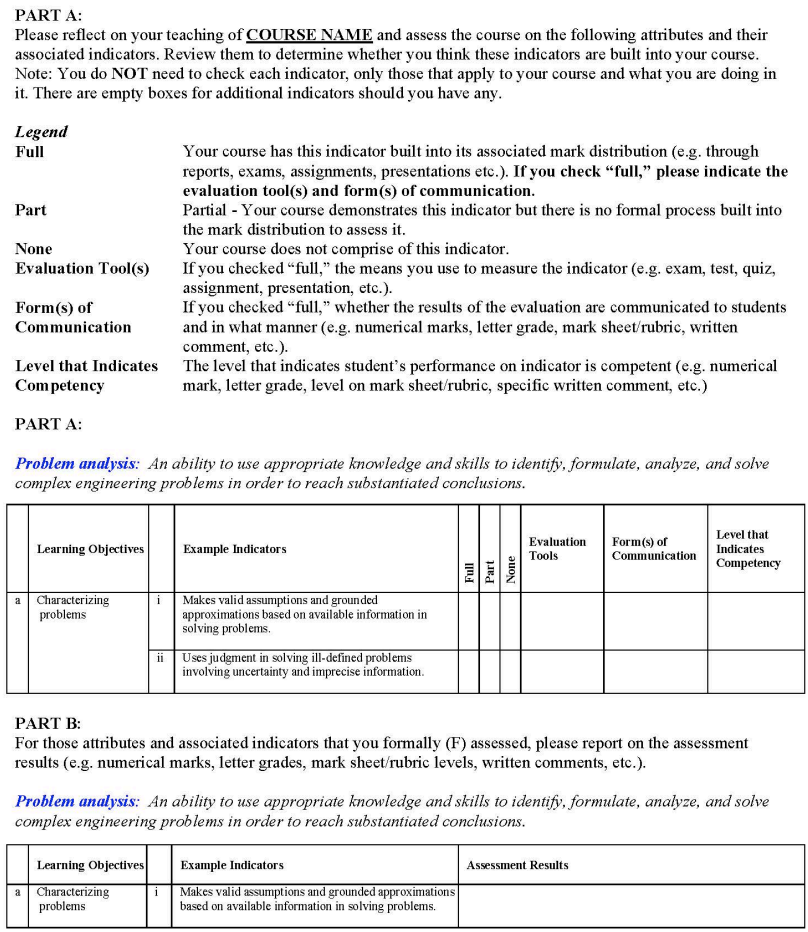

Fig. 1. Excerpts from the Faculty Attribute Checklist showing instructions for Part A and Part B.

Part A of the checklist asked instructors to mark the indicators as (i) Full: fully demonstrated and built into the associated mark distribution of their course; (ii) Part: demonstrated but not built into the formal assessment of the course; or (iii) None: not demonstrated in their course. If instructors chose Full, they were then asked to fill out three more categories for that indicator: (1) Evaluation Tools: the means that they used to measure the indicator (e.g. exam, test, quiz, assignment, presentation, etc.); (2) Forms of Communication: the way in which instructors communicated the results of the evaluation to their students (e.g. numerical or letter grade, marksheet/rubric, written comments, etc.); and (3) Level that Indicates Competency: the level that indicated students' performance on the indicator was proficient (e.g. in numerical grade, 7/10 might indicate competency). Part B of the checklist asked instructors to provide the assessment results for all of the indicators that they had marked as Full.

Data was collected in the following manner: In the second month of the Fall term 2012, instructors were provided with the Faculty Attribute Assessment Checklist and asked to self-administer Part A. Instructors were then asked to record the assessment results in Part B of the checklist once Fall term was complete. Nine instructors participated in the faculty/course attribute assessment study for the Fall term 2012.

\section{FINDINGS AND DISCUSSION}

The following results are to be considered a broad look at the faculty, with more emphasis on each individual program. They are not meant to be taken or read as a comparison between programs. They provide information into how these 4 attributes are manifest and measured in a few courses within each engineering program.

\subsection{Attribute/Indicator Checklist Results}

For Part A of the checklist instructors were asked to specify to what extent each attribute indicator was demonstrated and built into the associated mark distribution in their course (Full, Part or None). Table 1 illustrates the results.

Table 1: Number of indicators demonstrated and assessed in Faculty Attribute Assessment Checklist Fall 2012.

\begin{tabular}{|c|c|c|c|c|c|c|c|c|c|c|c|c|}
\hline \multirow{2}{*}{$\begin{array}{c}\text { Program } \\
\& \\
\text { Number } \\
\text { of } \\
\text { Courses }\end{array}$} & \multicolumn{3}{|c|}{$\begin{array}{c}\text { 2.Problem } \\
\text { Analysis } \\
13 \text { indicators }\end{array}$} & \multicolumn{3}{|c|}{$\begin{array}{l}\text { 4. Use of Eng. } \\
\text { Tools } \\
10 \text { indicators }\end{array}$} & \multicolumn{3}{|c|}{$\begin{array}{l}\text { 7. Commun. } \\
\text { Skills } \\
18 \text { indicators }\end{array}$} & \multicolumn{3}{|c|}{$\begin{array}{l}\text { 10. Ethics \& } \\
\text { Equity } \\
9 \text { indicators }\end{array}$} \\
\hline & 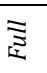 & $\frac{\pi}{\sigma}$ & $\stackrel{0}{\tilde{0}}$ & $\underset{\mathfrak{I}}{\mathbb{1}}$ & $\begin{array}{l}\pi \\
\vdots \\
\sigma\end{array}$ & ¿ี & $\underset{\mathbb{1}}{\mathbb{3}}$ & 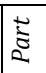 & ¿ & $\underset{1}{\mathbb{3}}$ & $\stackrel{\longleftarrow}{0}$ & $\stackrel{0}{\tilde{\delta}}$ \\
\hline $\begin{array}{c}\text { BIOE } \\
3\end{array}$ & 9 & 4 & 0 & 4 & 2 & 4 & 7 & 6 & 5 & 3 & 1 & 5 \\
\hline $\begin{array}{c}\text { CIVL } \\
2 \\
\end{array}$ & 11 & 0 & 2 & 6 & 1 & 3 & 10 & 1 & 7 & 0 & 0 & 9 \\
\hline $\begin{array}{c}\text { ECE } \\
1\end{array}$ & 8 & 0 & 2 & 3 & 1 & 0 & 0 & 0 & 18 & 0 & 0 & 9 \\
\hline $\begin{array}{c}\text { MECH } \\
\mathbf{3}\end{array}$ & 13 & 0 & 0 & 5 & 4 & 1 & 4 & 7 & 7 & 0 & 3 & 6 \\
\hline
\end{tabular}

Looking at the hard skills measured in this study, it was found that Problem Analysis indicators were assessed more frequently than Use of Engineering Tools (see Table 2).

Table 2: Comparison of hard skills: Program assessment of Problem Analysis vs. Use of Eng. Tools.

\begin{tabular}{|c|c|c|c|c|}
\hline \multirow{2}{*}{$\begin{array}{c}\text { Program \& } \\
\text { Number of } \\
\text { Courses }\end{array}$} & \multicolumn{2}{|c|}{$\begin{array}{c}\text { Problem } \\
\text { Analysis } \\
\mathbf{1 3} \text { indicators }\end{array}$} & \multicolumn{2}{c|}{$\begin{array}{c}\text { Use of Eng. } \\
\text { Tools } \\
\text { 10 indicators }\end{array}$} \\
\cline { 2 - 5 } & $\begin{array}{c}\text { \# of } \\
\text { indicators } \\
\text { assessed }\end{array}$ & $\begin{array}{c}\text { \% of } \\
\text { indicators } \\
\text { assessed }\end{array}$ & $\begin{array}{c}\text { \# of } \\
\text { indicators } \\
\text { assessed }\end{array}$ & $\begin{array}{c}\% \text { of } \\
\text { indicators } \\
\text { assessed }\end{array}$ \\
\hline $\begin{array}{c}\text { BIOE } \\
\mathbf{3}\end{array}$ & 9 & $69.2 \%$ & 4 & $40 \%$ \\
\hline $\begin{array}{c}\text { CIVL } \\
\mathbf{2}\end{array}$ & 11 & $84.6 \%$ & 6 & $60 \%$ \\
\hline $\begin{array}{c}\text { ECE } \\
\mathbf{1}\end{array}$ & 8 & $61.5 \%$ & 3 & $30 \%$ \\
\hline $\begin{array}{c}\text { MECH } \\
\mathbf{3}\end{array}$ & 13 & $100 \%$ & 5 & $50 \%$ \\
\hline
\end{tabular}

Comparing the soft skills showed Communication Skills was assessed more than Ethics and Equity, although to 
what extent was variable (see Table 3). Similar to the findings of the 2011-12 pilot study [3], the hard skills were demonstrated and assessed more often than the soft skills (see Table 4).

Table 3: Comparison of soft skills: Program assessment of Communication Skills vs. Ethics and Equity.

\begin{tabular}{|c|c|c|c|c|}
\hline \multirow{2}{*}{$\begin{array}{c}\text { Program \& } \\
\text { Number of } \\
\text { Courses }\end{array}$} & \multicolumn{2}{|c|}{$\begin{array}{c}\text { Communication } \\
\text { Skills } \\
\mathbf{1 8} \text { indicators }\end{array}$} & $\begin{array}{c}\text { Ethics \& } \\
\text { Equity } \\
\text { 9 indicators }\end{array}$ \\
\cline { 2 - 5 } & $\begin{array}{c}\text { \% of } \\
\text { assessed }\end{array}$ & $\begin{array}{c}\text { \% of } \\
\text { indicators } \\
\text { assessed }\end{array}$ & $\begin{array}{c}\text { \# of } \\
\text { indicators } \\
\text { assessed }\end{array}$ & $\begin{array}{c}\text { \% of } \\
\text { indicators } \\
\text { assessed }\end{array}$ \\
\hline $\begin{array}{c}\text { BIOE } \\
\mathbf{3}\end{array}$ & 7 & $38.9 \%$ & 3 & $33.3 \%$ \\
\hline $\begin{array}{c}\text { CIVL } \\
\mathbf{2}\end{array}$ & 10 & $55.6 \%$ & 0 & $0 \%$ \\
\hline $\begin{array}{c}\text { ECE } \\
\mathbf{1}\end{array}$ & 0 & $0 \%$ & 0 & $0 \%$ \\
\hline $\begin{array}{c}\text { MECH } \\
\mathbf{3}\end{array}$ & 4 & $22.2 \%$ & 0 & $0 \%$ \\
\hline
\end{tabular}

Table 4: Comparing assessment: Hard vs. soft engineering skills (Problem Analysis + Use of Eng. Tools vs. Communication Skills + Ethics and Equity.

\begin{tabular}{|c|c|c|}
\hline $\begin{array}{c}\text { Program } \\
\mathbf{8} \\
\begin{array}{c}\text { Number of } \\
\text { Courses }\end{array}\end{array}$ & $\begin{array}{c}\text { Hard Eng. Skills } \\
\text { (Prob. A. \& Use } \\
\text { of Tools) } \\
\% \text { of ind. }\end{array}$ & $\begin{array}{c}\text { Soft Eng. Skills } \\
\text { (Commun. Skills } \\
\text { \& Ethics) } \\
\% \text { of ind. }\end{array}$ \\
\hline $\begin{array}{c}\text { BIOE } \\
\mathbf{3}\end{array}$ & $54.6 \%$ & $22.3 \%$ \\
\hline $\begin{array}{c}\text { CIVL } \\
\mathbf{2}\end{array}$ & $72.3 \%$ & $27.8 \%$ \\
\hline $\begin{array}{c}\text { ECE } \\
\mathbf{1}\end{array}$ & $45.8 \%$ & $0 \%$ \\
\hline $\begin{array}{c}\text { MECH } \\
\mathbf{3}\end{array}$ & $75 \%$ & $11.1 \%$ \\
\hline
\end{tabular}

Out of the 4 programs in the study, one program did not assess Communication Skills; out of the 3 programs that did, Written and Visual learning objectives were emphasized. The Oral learning objective was only assessed once (See Table 5).

Table 5: Communication skills as assessed by learning outcomes.

\begin{tabular}{|c|c|c|c|c|c|c|}
\hline \multirow{3}{*}{$\begin{array}{c}\text { Program } \\
\& \\
\text { Number of } \\
\text { Courses }\end{array}$} & \multicolumn{6}{|c|}{ Communication Skills } \\
\hline & \multicolumn{2}{|c|}{$\begin{array}{c}\text { Written } \\
7 \text { indicators }\end{array}$} & \multicolumn{2}{|c|}{$\begin{array}{c}\text { Oral } \\
7 \text { indicators }\end{array}$} & \multicolumn{2}{|c|}{$\begin{array}{c}\text { Visual } \\
4 \text { indicators }\end{array}$} \\
\hline & $\begin{array}{l}\text { \# of } \\
\text { ind. }\end{array}$ & $\begin{array}{l}\% \text { of } \\
\text { ind. }\end{array}$ & $\begin{array}{l}\text { \# of } \\
\text { ind. }\end{array}$ & $\begin{array}{l}\% \text { of } \\
\text { ind. }\end{array}$ & $\begin{array}{l}\text { \# of } \\
\text { ind. }\end{array}$ & $\begin{array}{l}\text { \% of } \\
\text { ind. }\end{array}$ \\
\hline $\begin{array}{c}\mathrm{BIOE} \\
3\end{array}$ & 3 & $42.9 \%$ & 2 & $28.6 \%$ & 3 & $75 \%$ \\
\hline $\begin{array}{c}\text { CIVL } \\
2\end{array}$ & 6 & $85.7 \%$ & 0 & $0 \%$ & 4 & $100 \%$ \\
\hline $\begin{array}{c}\text { ECE } \\
1\end{array}$ & 0 & $0 \%$ & 0 & $0 \%$ & 0 & $0 \%$ \\
\hline $\begin{array}{c}\text { MECH } \\
3\end{array}$ & 4 & $57.1 \%$ & 0 & $0 \%$ & 0 & $0 \%$ \\
\hline
\end{tabular}

Only 1 program assessed Ethics and Equity, using a case study assignment. Of the 2 programs that were shown to demonstrate but not assess Ethics and Equity, emphasis was placed on the university expectations of student academic honesty. This reflects the research, which shows that ethics instruction in engineering education remains quite spotty, and is often viewed as teaching students the "laws and rules" [2], particularly of the academic institution. Teaching ethics continues to be a challenge, and is complicated by the contrary views of what faculty and students report comprises ethics education [2].

Also of interest are the 7 indicators out of 50 that were not demonstrated in any of the programs. They were:

- Use of Engineering Tools: (vii) Creates simple tools (sensory, software, etc.).

- Communication Skills/Oral: (ii) Delivers persuasive and professional formal presentations adapted to the needs of the audience; (vii) Explains and interprets results for various audiences and purposes.

- Ethics and Equity: (v) Determines and analyzes ethical risk components; (vi) Adheres to guidelines dictating use of intellectual property and contractual issues; (viii) Critically evaluates information for authority, currency, accuracy, reliability and objectivity; (ix) Discusses/analyzes social and legal issues regarding information (open access, privacy, intellectual property...).

There is a clear absence of the teaching and assessing of Ethics and Equity and of the Oral learning objective found in Communications Skills. There is also an absence of some of the higher-level cognitive competency indicators in Use of Engineering Tools. For the latter, it would be valuable to discover if the absent indicators are present in other courses within the programs. If not, it would be worth exploring if the absence reflects an area in the programs that needs fortifying, or if it is a reflection of an incompatibility of the attribute indicators for the programs. As for the soft skills, the research indicates that these attributes need additional representation in engineering education [10][2].

There were other trends worth noting for each program. Mechanical Engineering was comprised of a first year, third and fourth year course. All 13 indicators in Problem Analysis were either demonstrated or demonstrated and assessed in 2 out of 3 courses. For Use of Engineering Tools, of the 10 indicators, 5 were taught and assessed by at least one, and at times two courses, and 4 indicators were demonstrated but not assessed. Communication Skills was broken down into 3 learning objectives, Written, Oral and Visual, and had 18 potential indicators. Of these, 4 indicators were taught and assessed in 1 course, 7 indicators were demonstrated but not assessed, mostly in 1 course, and 7 indicators were not demonstrated. Of the 7 not demonstrated, all were indicators for Oral Communication Skills. Ethics and Equity was partially demonstrated in 3 out of 9 indicators.

In 2 third year Civil Engineering courses, 11 out of 13 indicators for Problem Analysis were fully demonstrated, and 2 indicators were not demonstrated. Six out of 10 indicators in Use of Engineering Tools were fully 
demonstrated; 3 indicators were not. For Communication Skills, all 10 attributes that were fully or partially demonstrated were in the Written or Visual learning objectives. Out of a possible 7 indicators, only one was partially demonstrated in Oral Communication Skills: (iii) Listens actively, confirms understanding and responds to questions and instructions appropriately. Ethics and Equity was not demonstrated.

Together, a second year and two third year Biosystems Engineering courses fully demonstrated 9 out of 13 indicators for Problem Analysis, with the rest partially demonstrated. Out of Use of Engineering Tools, the 4 indicators that were not demonstrated were indicators that required synthesis, creation and evaluation, higher level cognitive abilities [1]. For Communication Skills, the Written and Visual learning objectives were more fully or partially demonstrated than the Oral learning objective, which was fully demonstrated only once. Ethics and Equity was fully or partially demonstrated in 4 out of 9 indicators.

Computer Engineering had one course represented in the study, and of those data, Problem Analysis was fully demonstrated in 8 indicators. Use of Engineering Tools was fully demonstrated in 3 indicators, and partially in 1 . Communication Skills and Ethics and Equity were not demonstrated.

\subsection{Evaluation Tools}

Part A of the checklist asked instructors to describe the evaluation tools that they used in their course. Table 6 shows that there was a combination of 11 types of evaluations, with assignments designated by all nine instructors, and reports a close second, specified by eight instructors. The majority of instructors used a combination of the same number of evaluation tools to assess all attributes/indicators, with the most used being 7 tools and the least 2. At least three of the instructors showed clear evidence of further separating individual evaluation tools into smaller components to precisely measure the targeted indicator(s). For example, for Problem Analysis/Characterizing Problems (i) Makes valid assumptions and grounded approximations based on available information in solving problems, the instructor stipulated that "Assignment 1, Problem 1" measured this indicator, and broke down assessment results accordingly. This approach demonstrates a meticulous evaluation of the attribute, of which requires a dedicated amount of time. This is another area worth further exploration and discussion to determine how much precision is necessary and beneficial for both students and faculty.
Table 6: Evaluation tools used by instructors in Faculty Attribute Assessment Checklist Fall 2012.

\begin{tabular}{|c|c|l|}
\hline Evaluation Tools & $\begin{array}{c}\text { \# Instructors } \\
\text { Using Tool }\end{array}$ & $\begin{array}{l}\text { Examples of Tools and Number } \\
\text { of Times Reported }\end{array}$ \\
\hline Assignments & 9 & $\begin{array}{l}\text { - Hazard analysis } \\
\text { - Assignment 1 } \\
\text { - Safety guard 1 } \\
\text { - Case study 1 }\end{array}$ \\
\hline Term tests & 3 & \\
\hline Final exam & 6 & \\
\hline Midterm exam & 1 & \\
\hline Bridge \\
competition
\end{tabular}

Relevant is that the evaluation tool, presentation, is only used by one instructor. A potential way to increase the full demonstration of Communication Skills could be for faculty to have students present their reports - a popular evaluation tool - and asses them on the Oral learning objective. Of further interest is that one instructor recorded evaluation tools for several indicators that he checked as not being evaluated: discussion (conversational analysis) and use of tools (observation). These are authentic forms of assessment seldom used in engineering education [5] that provide a viable evaluation alternative. This is also noteworthy because the instructor is making a distinction between formative and summative assessment. Formative assessment is anecdotal, and normally used for feedback to improve both teaching and learning [7]. The increased use of formative assessment could be beneficial to engineering educators as they begin to emphasize an outcomes-based curriculum [7][11][13].

\subsection{Forms of Communication}

The checklist also asked instructors to record how they communicated assessment results to students. Five forms of communication were highlighted: Numerical marks, written comments, rubrics, letter grades, and verbal/oral communication, in descending order of use. Table 7 illustrates the breakdown of these forms of communication. 
Table 7: Forms of communication as reported by instructors in Faculty Attribute Assessment Checklist Fall 2012.

\begin{tabular}{|c|c|c|}
\hline $\begin{array}{c}\text { Forms of } \\
\text { Communication }\end{array}$ & $\begin{array}{c}\text { \# Instructors } \\
\text { Using Form }\end{array}$ & Additional Information \\
\hline $\begin{array}{c}\text { Rubrics/ Marksheet/ } \\
\text { Attribute Evaluation } \\
\text { Sheet }\end{array}$ & 3 & $\begin{array}{l}1 \text { instructor reported using } \\
\text { percentages. }\end{array}$ \\
\hline $\begin{array}{c}\text { Numerical Marks } \\
\text {-Numbers (i.e.) } \\
\text { 7/10 }\end{array}$ & 8 & $\begin{array}{l}\text { 3 of the } 6 \text { instructors clearly } \\
\text {-Percentages }\end{array}$ \\
\hline Letter Grade & 2 & $\begin{array}{l}\text { were part of a rubric, } \\
\text { marksheet, or evaluation sheet }\end{array}$ \\
\hline $\begin{array}{c}\text { Written Comments } \\
\text { Verbal }\end{array}$ & 6 & $\begin{array}{l}\text { 1 instructor reported using } \\
\text { verbal communication several } \\
\text { times even when there was no } \\
\text { assessment indicated. Could be } \\
\text { considered formative } \\
\text { assessment. }\end{array}$ \\
\hline $\begin{array}{c}\text { Communication/Oral } \\
\text { comments }\end{array}$ & 1 &
\end{tabular}

Instructors used a combination of 1 to 3 forms of communication, with numerical marks being by far the most popular, designated by 8 instructors, and written comments second most popular, designated by 6 . Interestingly, 3 out of the 6 instructors who recorded using written comments linked them to rubrics, an assessment tool that supports outcomes-based learning [10]. For this category, of interest was whether there was a change in the form of communication depending on the attribute/indicator being assessed. This didn't seem to be the case. Of note is that there was further evidence of the use of formative or anecdotal assessment, as one instructor wrote down verbal communication several times even when the indicators were marked as not being evaluated.

\subsection{Level that Indicates Competency}

Table 8 breaks down instructor descriptions of the 3 levels chosen to indicate competency.

Table 8: Level that indicates competency as reported by instructors in Faculty Attribute Assessment Checklist Fall 2012.

\begin{tabular}{|c|c|}
\hline \multicolumn{2}{|r|}{ Level That Indicates Competency } \\
\hline Category & Examples of Instructors' Descriptions \\
\hline Written Comments & $\begin{array}{l}\text { - "good or adequate" } \\
\text { - "meets expectations" } \\
\text { - Rubric-style comments (i.e.) Problem not organized } \\
\text { very well, since many sections of the solution were } \\
\text { missing. Problem organization acceptable. }\end{array}$ \\
\hline Numerical Marks & $\begin{array}{l}\text { - } 65 \% \text { and } 75 \% \text { - when assignment or course } \\
\text { project report level is } 75 \% \text { competency; when } \\
\text { final exam is included, competency level is } 65 \% \\
\text { - average of } 65 \% \text { with } 90 \% \text { as "high" for exam, tests } \\
\text { \& design project; average of } 60 \% \text { for all other } \\
\text { indicators } \\
-75 \% \\
-6 / 10 \text { for problem analysis; } 7 / 10 \text { for use of eng. } \\
\text { tools; } 9 / 15,60 \% \text { and grade of } C \text { for all written } \\
\text { communication; grade of C for oral communication } \\
\text { presentation; } 7 / 10 \text { for visual communication; } \\
\text { "meets expectations" on rubric for ethics; } 4 / 6 \text { for } \\
\text { ethics } \\
\text { - Min. } 52 \%\end{array}$ \\
\hline Letter Grades & $\begin{array}{l}\text { - Grade of C } \\
\text { - "Expected Levels of Competency": B+ to B to C+ - } \\
\text { grades descend as indicators ascend - expected } \\
\text { levels of proficiency fall as expected competency } \\
\text { seems to ascend }\end{array}$ \\
\hline
\end{tabular}

These data show that although 3 distinct categories were highlighted, written comments, numerical marks, and letter grades, there was a wide range of levels indicating competency, with no consistent approach to stating these levels. Within some instructors' checklists, the level of competency remained the same for all attributes and indicators. In other checklists, the competency levels changed, one dependent on the final exam, and another demonstrating decreasing competency levels as indicators became increasingly sophisticated. The question of how best to establish competency levels remains an area worth further investigation.

\subsection{Level that Indicates Competency and Assessment Results}

Table 9: Examples of levels that indicate competency and assessment results from Faculty Attribute Assessment Checklist Fall 2012 (abridged).

\begin{tabular}{|c|c|c|}
\hline $\begin{array}{l}\text { Attribute/Learning } \\
\text { Objective/Indicator }\end{array}$ & $\begin{array}{c}\text { Expected } \\
\text { Comp. }\end{array}$ & $\begin{array}{c}\text { Assessment Result } \\
\text { (Class Average) }\end{array}$ \\
\hline $\begin{array}{l}\text { 2. Problem } \\
\text { Analysis/Analysis/ } \\
\text { ii. Show insightful \& thorough } \\
\text { analysis of all solutions }\end{array}$ & $6 / 10$ & $\begin{array}{c}8.1 / 10 \\
\text { (2 students below } \\
\text { competency) }\end{array}$ \\
\hline $\begin{array}{l}\text { 7. Communication } \\
\text { Skills/Written/iii. Employs } \\
\text { proper process to produce } \\
\text { documents with appropriate } \\
\text { format, content, org., and tone } \\
\text { for various audiences. }\end{array}$ & $9 / 15$ & $\begin{array}{c}10.8 / 15 \\
(25 / 31 \text { students score of } 9 \\
\text { or better; } \\
\text { lowest score } 7)\end{array}$ \\
\hline $\begin{array}{l}\text { 2.Problem Analysis; 4.Use of } \\
\text { Engineering Tools; } \\
\text { 7.Communication Skills }\end{array}$ & \begin{tabular}{|r} 
Min. 52\% \\
in overall \\
evaluation
\end{tabular} & $\begin{array}{c}\text { Final Exam: } \\
3=33-50 \% \\
5=50-60 \% \\
4=60-70 \% \\
7=70-80 \% \\
7=\text { above } 80 \% \\
\text { Final Grade in Course: } \\
4=\text { below } \mathrm{C}+ \\
22=\text { above B }\end{array}$ \\
\hline \begin{tabular}{|l|}
$\begin{array}{l}\text { 2.Problem Analysis; 4.Use of } \\
\text { Engineering Tools }\end{array}$ \\
\end{tabular} & $6 / 10$ & $\begin{array}{c}\text { Instructor gave written } \\
\text { explanation. Stated “yes" to } \\
\text { students' competency in all } \\
\text { indicators, while explaining } \\
\text { student weaknesses. }\end{array}$ \\
\hline $\begin{array}{l}\text { 2.Problem Analysis/ } \\
\text { Characterizing Problems } \\
\text { i. Makes valid assumptions and } \\
\text { grounded approximations } \\
\text { based on available information } \\
\text { in solving problems. }\end{array}$ & $65 \%$ & $\begin{array}{l}\text { Assignments: } 85 \% \text {; Project: } \\
\text { 88\%; } \\
\text { Final exam: } 71.5 \%\end{array}$ \\
\hline $\begin{array}{l}\text { 2.Problem Analysis/ } \\
\text { Characterizing Problems } \\
\text { ii. Uses judgment in solving ill- } \\
\text { defined problems involving } \\
\text { uncertainty and imprecise } \\
\text { information. }\end{array}$ & $75 \%$ & $69 \%$ \\
\hline $\begin{array}{l}\text { 2.Problem Analysis/ } \\
\text { Modeling } \\
\text { i. Uses models (physical, } \\
\text { mathematical...) to } \\
\text { communicate engineering } \\
\text { processes and systems. }\end{array}$ & $75 \%$ & $\begin{array}{l}\text { Assignments: } 85 \% \text {; Projects } \\
88 \%\end{array}$ \\
\hline $\begin{array}{l}\text { 2. Problem } \\
\text { Analysis/Characterizing } \\
\text { Solutions } \\
\text { i. Makes valid assumptions and } \\
\text { grounded approximations } \\
\text { based on available information } \\
\text { in solving problems. }\end{array}$ & $\mathrm{B}+$ & $\mathrm{C}+$ \\
\hline $\begin{array}{l}\text { 2. Problem } \\
\text { Analysis/Characterizing } \\
\text { Solutions } \\
\text { ii. Uses judgment in the process } \\
\text { of analyzing ill-defined } \\
\text { problems involving uncertainty } \\
\text { and imprecise information. }\end{array}$ & $\mathrm{B}+$ & $\mathrm{C}+$ \\
\hline
\end{tabular}


Table 9 is an abridge data set that provides a comparative look at the levels that indicate competency and the reported assessment results. Eight out of 9 instructors recorded assessment results. (The complete table may be obtained from the authors upon request.)

For the most part, student averages were above levels that indicated competency. There were exceptions. In one course, 10 out of 27 indicators showed student averages below levels that indicated competency; in another, 7 out of 10 indicators were below expected competency levels. One instructor reported that $64 \%$ of students demonstrated competency. These data demonstrate that there are always going to be a percentage of students who don't demonstrate competency. This adds another dimension to the question of establishing competency levels, and asks us to think about thresholds and targets, and percentage of students we expect to achieve competency.

\section{CHALLENGES AND NEXT STEPS}

We realized that having a few instructors from each program complete a checklist that only focuses on 4 attributes may not effectively provide us data with depth or breadth. Preferably, having a few instructors fill out a checklist that targets all 12 attributes, or all instructors fill out a checklist that highlights a few attributes each year, would, over several years, create a more complete picture of how the 12 graduate attributes are manifest and measured in our programs. However, this study is a pilot, and we are continuing to discuss how to more completely and consistently measure attributes based on our findings.

One finding is that it can be challenging to obtain completed checklists even when instructors willingly agree to participate. This difficulty could be attributed to a number of factors. There was some evidence that instructors did not understand what the checklist was asking them to do, particularly in terms of indicating competency levels; and there were times when the checklist was not a priority for instructors.

There was also a concern that the list of indicators developed is too long and unwieldy. Some instructors thought that the indicators might not be reflecting program assessment needs. Presently, we are in the process of revisiting this indicator list. Further, some of the terminology in the checklist needs revision to better reflect faculty's shared understanding of assessment, indicators and competency levels. A common language is essential to a successful attribute assessment process [4][5]. Education, discussion and consensus are needed to establish the infrastructure to create a shared outcomesbased assessment language [12].

Additionally, complications were generated due to delayed decision-making. This year's checklist was administered to instructors late in the term. There is no perfect time for checklists when considering the workload of teaching faculty, but there are better times. A complete plan of action needs to be in place, ideally before the beginning of the semester, so participants are well informed in advance [12]. The consideration of administering the checklist in a workshop style setting might also be a more fruitful, less arduous approach.

Perhaps due to the length of the checklist and the delayed administration, and often due to misgivings surrounding the categories - especially competency levels - there were times when instructors put the checklist aside. This points to the challenges inherent in emphasizing an outcomes-based teaching and assessment pedagogy [11][13], and highlights areas that need further attention, such as establishing student competency levels $[6][8][11][2]$.

Laying the groundwork for faculty buy-in [4][9] could go a long way in helping alleviate some of the potentially negative or indifferent attitudes that could surround a checklist such as this. It is not hard to imagine that filling out a checklist is not immediately seen as helpful for either instructors or their students, and could be perceived as busy work, of which faculty are already inundated. Therefore, professional development and opportunities for conversations about indicators and assessments, a welltimed and less onerous method for administering the checklist, timely feedback given to and solicited from participants to help shape future checklists and other accreditation assessment tools are all essential for developing faculty interest.

\section{Acknowledgements}

The authors would like to thank the following instructors for their work in helping us obtain these data: Danny Mann, Stefan Cenkowski, Qiang Zhang, Marolo Alfaro, Dagmar Svecova, Ken Ferens, Juan Abello, Yunhua Luo, and Subramaniam (Bala) Balakrishnan. We would also like to thank Paul Labossiere for his efforts formatting this paper. This work would not have been possible without all of their valuable input and resources. This research study was funded by Dr. Ingram's University of Manitoba Faculty of Engineering Start-up Grant.

\section{References}

[1] Benjamin, S. Bloom (Ed.), Max D. Engelhart, Edward J. Furst, Walker H. Hill and David R. Krathwohl, Taxonomy of educational objectives: The classification of educational goals. Handbook 1: The cognitive domain. New York, NY: Longmans, Green \& Co., 1956. 207 pp.

[2] Matthew A. Holsapple, Donald D. Carpenter, Janel A. Sutkus, Cynthia J. Finelli and Trevor S. Harding, "Framing faculty and student discrepancies in engineering ethics delivery," Journal of Engineering Education, vol. 101, no. 2, pp. 169-186, 2012. 
[3] Sandra Ingram, Jillian Seniuk Cicek and Nariman Sepehri, "The Attribute assessment process at the University of Manitoba," in Proc. CEAA Canadian Engineering Conf., CEEC12, (Winnipeg, MB; 17-21 June 2012), 7 pp., 2012.

[4] Jack McGourty, Catherine Sebastian and William Swart, "Developing a comprehensive assessment program for engineering education," Journal of Engineering Education, vol. 87 , no. 4 , pp. 355-361, 1998.

[5] Barbara M. Olds, Barbara M. Moskal and Ronald L. Miller, "Assessment in engineering education: Evolution, approaches and future collaborations," Journal of Engineering Education, vol. 94, no. 1, pp. 13-25, 2005.

[6] Honor J. Passow, "Which ABET competencies do engineering graduates find most important in their work?," Journal of Engineering Education, vol. 101, no. 1, pp. 95118, 2012.

[7] Gloria M. Rogers, "EC2000 and measurement: How much precision is enough?," Journal of Engineering Education, vol. 89, no. 2, pp. 161-166, 2000.

[8] Katherine Scales, Christi Owen, Subodh Shiohare and Michael Leonard, "Preparing for program accreditation review under ABET engineering criteria 2000: Choosing outcome indicators," Journal of Engineering Education, vol. 87, no. 3, pp. 207-210, 1998.

[9] Joseph Shaeiwitz, "Outcomes assessment in engineering education," Journal of Engineering Education, vol. 85, no. 3, pp. 239-246, 1996.

[10] Larry J. Shuman, Mary Besterfield-Sacre and Jack McGourty, "The ABET "professional skills" - can they be taught? Can they be assessed?," Journal of Engineering Education, vol. 94, no. 1, pp. 41-55, 2005.

[11] Neelam Soundarajan, "Preparing for accreditation under EC 2000: An experience report," Journal of Engineering Education, vol. 91, no. 1, pp. 117-123, 2002.

[12] Joni E. Spurlin, "Assessment methods used in undergraduate program assessment," in Designing Better Engineering Education Through Assessment, Joni E. Spurlin, Sarah A. Rajala, \& Jerome P. Lavelle (eds.). Sterling, VA: Stylus Publishing, pp. 59-116, 2008.

[13] Peter Wolf and Warren Stiver, "Graduate attributes: Intentional mapping and assessment portfolios," in Proc. CEAA Canadian Engineering Conf., CEEC11, Andy Fisher (ed.) (St. John's, NL; 6-8 June 2011), pp. 4, 2011. 